\title{
FAILURE RISK ANALYSIS GLASS BOWL PRODUCTION PROCESS USING FAILURE MODE EFFECT ANALYSIS AND FAULT TREE ANALYSIS METHODS (A CASE STUDY)
}

\author{
Ikhwan Syahtaria, A. Mashudi, Bambang Suharjo \\ ${ }^{1}$ Indonesian Naval Technology College, \\ STTAL-Bumimoro-Morokrembangan, Surabaya 60187, Indonesia
}

\begin{abstract}
Product defects are a natural thing in a production process, but it would be better to avoid them. $X Y Z$ Industries is a company that produces glassware in the form of the glass bowl. The production failure experienced by this company is still high at $3.1 \%$ of the total production while the defect target that the company wants is $2 \%$. The purpose of this study was to identify the types of defects that occur in glass bowl products on the production floor based on the results of searches of literature studies and deep interviews with employees, get the risk of failure of the largest production process in the RPN (Risk Priority Number) value of the FMEA method then analyzed again using the FTA method and determine the proposed improvements needed based on the analysis of defects that occur in glass bowl products, thus minimizing product defects and increasing company profits. In this study using the method of Failure Mode and Effect Analysis (FMEA) and the Fault Tree Analysis (FTA) method to identify failures that occur and provide prevention solutions. Based on the results of data processing, the proposed improvements given to the company as a whole are the company in order to pay more attention to the maintenance of the machine so that the machine can avoid the failure of its function.
\end{abstract}

Keywords: Defective Product, Failure Mode and Effect Analysis, Fault Tree Analysis, Risk Priority Number.

\section{INTRODUCTION.}

$\mathrm{XYZ}$ Industry is one of the companies engaged in manufacturing, is a company that produces glass bowl. This company still has problems in many types and numbers of defective products caused by various factors that cause a decrease in quality which results in a decrease in profits obtained by the company.

In fulfilling the demand for glass bowls, XYZ Industries runs the production process by dividing working hours into 2 daily shifts where each shift has 8 hours of work carried out continuously for 6 working days. In the production process, there are many defects in the products produced, in this case glass production. This resulted in losses for $X Y Z$ Industries.
Table 1. The number of Defective Production at $\mathrm{XYZ}$ Industries.

\begin{tabular}{|c|c|c|c|}
\hline $\begin{array}{c}\text { Production } \\
\text { week }\end{array}$ & $\begin{array}{c}\text { Amount of } \\
\text { production } \\
\text { (pcs) }\end{array}$ & $\begin{array}{c}\text { Amount } \\
\text { of } \\
\text { Defect } \\
\text { (pcs) }\end{array}$ & $\begin{array}{c}\text { percentage } \\
\text { of defects } \\
(\%)\end{array}$ \\
\hline 1 & 10124 & 226 & 2,23 \\
\hline 2 & 5708 & 177 & 3,10 \\
\hline 3 & 9995 & 212 & 2,12 \\
\hline 4 & 7894 & 225 & 2,85 \\
\hline 5 & 4440 & 110 & 2,48 \\
\hline 6 & 8550 & 202 & 2,36 \\
\hline 7 & 13004 & 309 & 2,38 \\
\hline 8 & 12785 & 344 & 2,69 \\
\hline 9 & 8291 & 176 & 2,12 \\
\hline 10 & 10104 & 306 & 3,03 \\
\hline
\end{tabular}

Based on Table 1 above it is shown that the percentage of the number of defective products experienced by this company is still quite high with 
an average of $2.54 \%$ above the percentage set by the company which is $2 \%$.

To overcome the above problems, the need for an appropriate method to find the root causes of failure problems to minimize the level of product defects in this company. The method that can be used to overcome product defects is by identifying the work process flow on the company's production floor with the Fault Tree Analysis (FTA) method, then making an analysis for improvement using the Failure Mode and Effect Analysis (FMEA) method. FMEA is a technique used to define, identify, and eliminate failures and problems in the production process, after which weighting and sorting are carried out based on the Risk Priority Number (RPN).

The reason for choosing a glass bowl product to be examined is because the company has the most glass bowl products that experience defects in the production process compared to other products. So this research was conducted with the aim to identify the types of defects that occur in glass bowl products on the plate production floor based on the results of the search for literature studies and deep interviews with employees to get the risk of failure of the largest production process in the RPN (Risk Priority Number) value of The FMEA method is then re-analyzed using the FTA method and determines the proposed improvements that are needed based on the analysis of defects that occur in glass bowl products. Based on data processing using FMEA and FTA methods, it can identify the failure modes that occur in the process of making glass bowls in this company.

This paper has many literature to support the research, such as literature with title Fault Tree Analysis of Clinical Alarm (Hyman and Johnson, 2008), Fault Tree Analysis in Construction Industry for Risk Management (Swarna and Venkatakrishnaiah, 2014), Fault Tree Analysis Of Solar Concentrators (Catic et al., 2013), Estimation of Failure Probability Using Fault Tree Analysis and Fuzzy Logic for CO2 Transmission (Baig and Ruzli, 2014), Power System Reliability Evaluation Using Fault Tree Approach Based on Generalized Fuzzy Number (verma, Kumar and Singh, 2012), Modified Prioritization Methodology for Risk Priority Number in Failure Mode and Effects Analysis (Sellappan and Palanikumar, 2013), Risk Assessment Of Mobile Phones Using Failure Mode And Effects Analysis (Bašić and Popović, 2016), Application Of Failure Mode \& Effect Analysis (Fmea) For Continuous Quality Improvement - Multiple Case Studies In Automobile Smes (Doshi and Desai, 2016), Failure Mode and Effect Aanalysis on Power Plant Boiler (Putraa and Purba, 2018), Software Failure Analysis at Architecture Level using FMEA (Nggada, 2012), FMEA Based Risk Assessment of Component Failure Modes in Industrial Radiography (Pandey et al., 2016), Failure mode effect analysis and fault tree analysis as a combined methodology in risk management (Wessiani and Yoshio, 2017).

This research is organized as follows, chapter 1 introduction, chapter 2 shows material and methodology, chapter 3 shows the results of data and discussion, chapter 4 conclusion.

\section{MATERIAL/METHODOLOGY.}

\subsection{Fault Tree Analysis (FTA)}

Error tree analysis is a failure analysis that is used when an unwanted state of a system is then analyzed using Boolean logic to combine a series of events at a lower level (Patil et al., 2016). FTA is a very complex and popular technology reliability analysis method based on probability theory and Boolean logic (Rusin and Wojaczek, 2012). To analyze a failure using the error tree analysis begins, it must begin with a "peak event" which is generally displayed with related events and rectangles based on a 
logical relationship with the top event that sank below, branching down like a tree (Gharahasanlou et al., 2014). FTA is a very effective risk assessment tool but when it comes to a reasonably complex system, that includes a large number of equipment and process variables, the fault tree becomes enormous and takes quite of a time to be completed. A team of engineers works over it and even then it may take years to complete without the surety of weather all the failure possibilities are considered or not.

The concept of partial failure in a fault tree does not exist. If the equipment is partially working it is considered as fully unavailable or in failure mode. This partial failure changes the reliability of a system but the FTA has no effect of such condition in its results. If a fault tree is developed by different safety professionals, it will be of a different nature depending on the developer. This makes the fault tree a non-generic or inexact in nature. The probability calculation for a top event requires the failure data of all the events in the fault tree that are usually not known or not accurately known that decreases the credibility of the analysis. On the other hand, the biggest advantage of using FTA is that it starts from a top event that is selected by the user for a specific interest and the tree developed will identify the root cause. The FTA has the ability to be used with the computer and generate results using computer applications for improved analysis.

Problems found in this study namely the problem of glass bowl defects found in $\mathrm{XYZ}$ Industries. FTA is used for find and identifies the root causes of the problem from failure modes that have RPN values highest. The root cause of the problem can be known by making direct observations on the production process, observing machines that work and also interviewed employees work at $\mathrm{XYZ}$ Industries.

\subsection{Failure Mode and Effect Analysis}

FMEA is a methodology used in product development and operations management to analyze all possible failure modes in a system to classify severity and likelihood failure (Ambekar, Edlabadkar and Shrouty, 2013). FMEA is a method that can be used as an individual project tool (Parsana and Patel, 2014). FMEA proved to be very effective and efficient to be applied in an effort to analyze elements that can cause both part and overall of system failure (Popović, Vasić and Petrović, 2010). Failure modes and effects analysis (FMEA) has been considered as a fairly effective and effective analysis tool used in some developed countries such as Japan, United States and several countries in Europe in various industries, such as automobiles, electronics, households, energy generation, telecommunications, health care services, pharmacy, e-commerce, product design (Nguyen, Tai and Shu, 2016). The method used in the FMEA method is to estimate the probability based on Priority Risk Number (RPN) (Alsubiaee et al., 2017). FMEA is also a very systematic method for identifying and preventing various product and process problems before they occur (Tsarouhas and Arampatzaki, 2015). Generally, in a system, design, process, or service may have several modes of failure or cause and the effect they cause (Wang et al., 2009). System FMEAs are used to analyze concepts for systems and subsystems in the early stages. Is focusing on potential failure modes 
associated with the proposed functions of a concept proposal caused by design decisions that introduce deficiencies (these include "design" decision about the process layout) and Include the interaction of multiple systems and the interaction between the elements of a system at concept stages (this may be operation interaction in the process).

Design FMEAs are used to analyze products before they are released to production. Is focusing on potential failure modes of products caused by design deficiencies and identify the potential designated characteristics called "special characteristics". Process FMEAs are used to analyze manufacturing and assembly processes. Is focusing on potential product failure modes caused by manufacturing or assembly process deficiencies, confirm the need for special controls in manufacturing and confirm the designated potential "special characteristics" from the design FMEA, and identify the process failure modes that could violate government regulations or compromise employee safety.

The FMEA product considers all required functions from components, products, and systems up to the layout of properties and characteristics. Possible deviations are also considered and the action that must be taken in order to meet the requirements is defined. The FMEA process considers all processes for the manufacture of components, products, and systems up to the definition of the factors, which influence these processes. Possible deviations are considered and the actions needed to secure the processes and product characteristics are defined. The basic FMEA combines experiences obtained from previous developments and ongoing production and is to be used as the basis for new developments. New findings should be added to the basic FMEA as appropriate. It reflects the robustness of the products and manufacturing processes.

FMEA prioritizes failure mode analysis through the production process and does not depend on product design changes that can cause a failure in a process. FMEA is usually resolved according to labor, machine, method, material, measurement, and environmental considerations. Each component has its own component, which works individually, together, or even an interaction to produce a failure.

Severity is an assessment of seriousness from the effects. In any sense failures that arise will be judged how big level of seriousness. There is a relationship directly between effect and severity. As an example, if the effect is a critical effect, then the severity value will be high. Therefore, if the effect is not an effect critical, the severity value will be very low.

The occurrence is the possibility that the cause will occur and produce the form of failure during the product usage period. The occurrence is an adjusted rating with estimated frequencies and or numbers cumulative of failures that can occur.

Detection values are associated with a current control. Detection is measurement against the ability to control/control failure that can occur.

This value is a product of results multiplication of severity, incidence rate, and detection level. RPN determines the priority of failure. RPN has no value or meaning. Value it is used to rank process failures potential. 
The RPN value can be indicated by the equation as follows :

RPN $=$ severity $x$ occurrence $x$ detection

\subsection{Research Methodology}

To solve problems in the observed research, steps are needed and determined to describe the approach and model of the problem. The steps taken are:

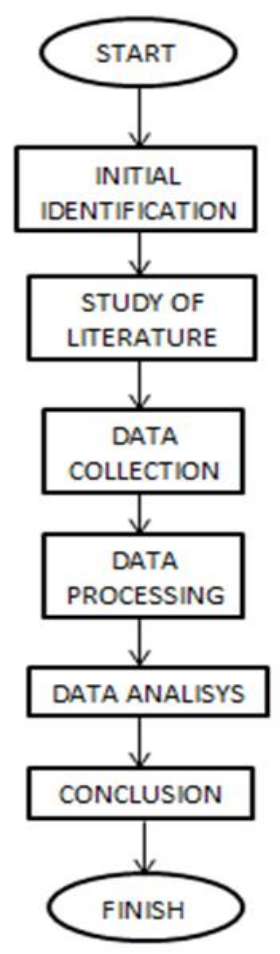

Fig. 2. Research Methodology Flowchart.

Target: The purpose of this study is to find and analyze the factors that cause product defects in glass bowl production work.

Steps: The step of this research is step 1 insert interview data in a quantitative table, step 2 does analysis test, step 3 analyze the delay of using FTA and FMEA, step 4 provides suggestions for improvements and conclusions.

Table 2. Mode of Failure of glass bowl products $\mathrm{XYZ}$ Industries

\begin{tabular}{|c|c|}
\hline Tool's name & Potential Failure Mode \\
\hline Ball Mill & $\begin{array}{l}\text { 1. Raw Material is not } \\
\text { completely destroyed. } \\
\text { 2. Weighing errors. } \\
\text { 3. Error in grading the raw } \\
\text { material. }\end{array}$ \\
\hline Viromagnetic & $\begin{array}{l}\text { 1. There are still levels of iron } \\
\text { in the raw material. } \\
\text { 2. The machine cannot sift } \\
\text { ingredients stable. }\end{array}$ \\
\hline Spray Drier & $\begin{array}{l}\text { 1. Addictive ingredients. } \\
\text { 2. Moisture content is less or } \\
\text { more than } 1.8 \%-2.2 \%\end{array}$ \\
\hline $\begin{array}{l}\text { Dust Press } \\
\text { Machine }\end{array}$ & $\begin{array}{l}\text { 1. Granulate } \\
\text { 2. Error forming a glass bowl. } \\
\text { 3. There are still air bubbles in } \\
\text { the dust press process }\end{array}$ \\
\hline Roller & Unstable roller use \\
\hline Firing & $\begin{array}{l}\text { 1. Temperature is not stable } \\
\text { 2. The material does not match } \\
\text { the Kiln temperature }\end{array}$ \\
\hline Glazier & $\begin{array}{l}\text { 1. There is dust on glazier } \\
\text { material } \\
\text { 2. The operator does not } \\
\text { provide glazier according to } \\
\text { SOP (Human Error) }\end{array}$ \\
\hline Finishing & $\begin{array}{l}\text { There is an air cavity in product } \\
\text { packaging }\end{array}$ \\
\hline
\end{tabular}

\section{RESULT AND DISCUSSION.}

\subsection{Analysis of Factors Cause Product \\ Failure Using the Failure Mode and Effects Analysis (FMEA) Method}

Table 3. Stages of the Plate Production Process

\begin{tabular}{|c|l|}
\hline No & \multicolumn{1}{|c|}{ Product Process } \\
\hline 1 & $\begin{array}{l}\text { Raw Material is destroyed using a ball } \\
\text { mill machine for 18 hours then weighed } \\
\text { in the laboratory according to the } \\
\text { Standart Operation Procedure. }\end{array}$ \\
\hline 2 & $\begin{array}{l}\text { Processed products are stored in large } \\
\text { containers for 1 day, it aims to cool the } \\
\text { raw material that has been processed }\end{array}$ \\
\hline 3 & $\begin{array}{l}\text { After cold, the raw material is pumped } \\
\text { and sieved with the strength of 150 } \\
\text { mass and inserted into Viromagnetic, } \\
\text { the aim is to attract iron content in the } \\
\text { raw material. }\end{array}$ \\
\hline 4 & $\begin{array}{l}\text { After being processed with } \\
\text { Viromagnetic, the processed product will } \\
\text { be reprocessed using Spray Drier } \\
\text { machine, this tool aims to separate the } \\
\text { water from the pulp and pulp produced } \\
\text { in the form of dust. }\end{array}$ \\
\hline 5 & $\begin{array}{l}\text { Then the dust produced will be pressed } \\
\text { with high pressure using a 900-07 DPM } \\
\text { machine. }\end{array}$ \\
\hline
\end{tabular}




\begin{tabular}{|c|l|}
\hline 6 & $\begin{array}{l}\text { The output that comes out of the DPM } \\
\text { engine will be formed round with the } \\
\text { help of the operator. }\end{array}$ \\
\hline 7 & $\begin{array}{l}\text { The product will be put into the train } \\
\text { then the combustion process is carried } \\
\text { out on the Kiln engine for } 24 \text { hours with } \\
\text { a temperature of } 800^{\circ}-900^{\circ} \mathrm{C}\end{array}$ \\
\hline 8 & $\begin{array}{l}\text { After the burnt is done the resulting } \\
\text { output is in the form of Biscuit (ceramic } \\
\text { half-baked) }\end{array}$ \\
\hline 9 & $\begin{array}{l}\text { Biscuit will be given a glazing liquid to } \\
\text { make it shiny. }\end{array}$ \\
\hline 10 & $\begin{array}{l}\text { Biscuit will be burned back to the Kiln } \\
\text { machine with a temperature of } 1200^{\circ}- \\
1350^{\circ} \mathrm{C} \text { for } 24 \text { hours to become a white } \\
\text { body. }\end{array}$ \\
\hline 11 & Finishing \\
\hline
\end{tabular}

Table 4. Severity Value

\begin{tabular}{|l|c|}
\hline \multicolumn{1}{|c|}{ Potential Failure Mode not } & Severity \\
\hline $\begin{array}{l}\text { Raw Materials are } \\
\text { destroyed perfect }\end{array}$ & 4 \\
\hline Breakdown Machine & 4 \\
\hline Human error (error weigh) & 8 \\
\hline $\begin{array}{l}\text { Grading errors in mixing raw } \\
\text { material }\end{array}$ & 8 \\
\hline $\begin{array}{l}\text { There are still iron levels in raw } \\
\text { material }\end{array}$ & 4 \\
\hline $\begin{array}{l}\text { The machine can't sieve } \\
\text { ingredients stable. }\end{array}$ & 9 \\
\hline Addictive & 4 \\
\hline $\begin{array}{l}\text { Water content is less or more } \\
\text { from 1.8\% -2.2\% }\end{array}$ & 7 \\
\hline Granulate & 7 \\
\hline $\begin{array}{l}\text { Human Error (Error } \\
\text { form a glass bowl) }\end{array}$ & \\
\hline
\end{tabular}

After determining the severity value, the next step is to determine the Occurrence value obtained based on the calculation of defective data and occurrence parameters based on the parameters that have been made by Stamatis, then the occurrence value is obtained. The parameters used are the assurance parameters that Stamatis made in 1995.

Table 5. Occuration Value Glass Bowl Process

\begin{tabular}{|l|c|}
\hline Potential Failure Mode & Occurrence \\
\hline $\begin{array}{l}\text { Raw Material is not destroyed } \\
\text { perfectly }\end{array}$ & 3 \\
\hline Breakdown Machine & 1 \\
\hline Human error (error weigh) & 2 \\
\hline
\end{tabular}

\begin{tabular}{|l|c|}
\hline $\begin{array}{l}\text { Error grading on mixing raw } \\
\text { material }\end{array}$ & 2 \\
\hline $\begin{array}{l}\text { There is still iron content in the } \\
\text { raw material }\end{array}$ & 3 \\
\hline $\begin{array}{l}\text { The machine cannot sift the } \\
\text { ingredients with stability. }\end{array}$ & 1 \\
\hline Addictive Material & 4 \\
\hline $\begin{array}{l}\text { Water content is less or more } \\
\text { than } 1.8 \%-2.2 \%\end{array}$ & 2 \\
\hline $\begin{array}{l}\text { Granulate (less good } \\
\text { ingredients) }\end{array}$ & 2 \\
\hline $\begin{array}{l}\text { Human Error (Error forming a } \\
\text { glass bowl) }\end{array}$ & 2 \\
\hline $\begin{array}{l}\text { There are still air bubbles in the } \\
\text { process of dust press }\end{array}$ & 6 \\
\hline Human Error & 3 \\
\hline Use of unstable rollers & 2 \\
\hline Temperature is not stable & 2 \\
\hline $\begin{array}{l}\text { The material does not match } \\
\text { Kiln temperature }\end{array}$ & 5 \\
\hline $\begin{array}{l}\text { There is dust on the glazier } \\
\text { material }\end{array}$ & 5 \\
\hline $\begin{array}{l}\text { Operators don't give glaciers } \\
\text { in accordance with soP } \\
\text { (Human Error) }\end{array}$ & 5 \\
\hline Image quality is not good \\
\hline Human Error \\
\hline There is an air cavity & 4 \\
\hline
\end{tabular}

After determining the occuration value, the next step is to determine the value of detection obtained from glass bowl defects and deep interviews with the parties concerned. The parameters used are parameter detection that was made by Stamatis in 1995.

Table 6. Detection Value Glass Bowl Process

\begin{tabular}{|l|c|}
\hline Potential Failure Mode & Detection \\
\hline $\begin{array}{l}\text { Raw Material is not destroyed } \\
\text { perfectly }\end{array}$ & 4 \\
\hline Breakdown Machine & 1 \\
\hline Human error (error weigh) & 3 \\
\hline $\begin{array}{l}\text { Error grading on mixing raw } \\
\text { material }\end{array}$ & 3 \\
\hline $\begin{array}{l}\text { There is still iron content in the } \\
\text { raw material }\end{array}$ & 4 \\
\hline $\begin{array}{l}\text { The machine cannot sift the } \\
\text { ingredients with stability. }\end{array}$ & 1 \\
\hline Addictive Material & 4 \\
\hline $\begin{array}{l}\text { Water content is less or more } \\
\text { than } 1.8 \%-2.2 \%\end{array}$ & 3 \\
\hline $\begin{array}{l}\text { Granulate (less good } \\
\text { ingredients) }\end{array}$ & 3 \\
\hline Human Error (Error forming a & 3 \\
\hline
\end{tabular}




\begin{tabular}{|l|l|}
\hline glass bowl) & \\
\hline $\begin{array}{l}\text { There are still air bubbles in the } \\
\text { process of dust press }\end{array}$ & 6 \\
\hline Human Error & 5 \\
\hline Use of unstable rollers & 3 \\
\hline Temperature is not stable & 3 \\
\hline $\begin{array}{l}\text { The material does not match Kiln } \\
\text { temperature }\end{array}$ & 6 \\
\hline $\begin{array}{l}\text { There is dust on the glazier } \\
\text { material }\end{array}$ & 6 \\
\hline $\begin{array}{l}\text { Operators don't give glaciers } \\
\text { in accordance with SOP (Human } \\
\text { Error) }\end{array}$ & 5 \\
\hline Image quality is not good & 6 \\
\hline Human Error & 6 \\
\hline There is an air cavity & \\
\hline
\end{tabular}

After determining the value of severity, occurrence, and detection, RPN values can then be calculated for each of these failure modes. Table 7 is a failure mode with each RPN value. Failure mode with the largest RPN value is a priority for corrective action and failure mode which has the largest RPN value will be analyzed using the FTA (Fault Tree Analysis) method.

\subsection{Analysis using Fault Tree Analysis} (FTA)

Analysis of Fault Tree Analysis (FTA) is an analysis used to find out the root cause of a problem. FTA is a method in the form of a root cause tree, while the determination of FTA is done in a failure mode that has the highest RPN value in the FMEA method. Where in this case the failure mode that has the highest RPN value is that the product has air bubbles with an RPN value of 432 , so this failure mode needs to be analyzed to determine the root cause of the existing problem.

The forming process is the process of forming raw materials into a glass bowl in the form of a white body. in the forming part of the machine used are DPM 900-07, Roller and Kiln. Forming part is a part that is often a defective factor in glass bowl products, because the forming machine used is a machine that works 24 hours without stopping. As such, it will result in a device that is used on the machine experiencing a failed operation. Products with air bubbles are a priority to improve recommendations because they have the highest RPN value. The cause of the product is that there are air bubbles on the DPM 900-07 engine where air leaks occur and engine performance decreases. The escape of the air flow caused by the leaking of the hydraulic channels caused by the engine wind filter was damaged, while the damaged wind filter was due to high wind pressure, besides the escape of air flow was caused by human errors or operator errors that were not accurate in DPM 900- engine settings 07 . In addition the product has air bubbles also caused by a decrease in engine performance, this is due to inappropriate wind pressure, this is due to human error or operator error in regulating air flow on the engine, other than that it can cause wind pressure not accordingly the cylinder head is damaged so that the air setting becomes unstable and uncontrolled. In addition, damaged bearings can result in damaged engine performance due to the lack of wear and flat head lubrication, and the last cause of the decline in engine performance is a clogged injection pump that caused by dirty O-seal this is due to the lack of regular maintenance of the machine. The mode of potential failure in the process of making glass bowls at $\mathrm{XYZ}$ Industries consists of 20 types of failures. The failure mode is obtained based on the failure of the machine/process type of machine operating in the process of making a glass bowl. Of all the parts 
contained in $\mathrm{XYZ}$ Industries, the forming part is the part that has a high RPN value because the forming part is the part that most often results in defects. At forming has a machine that works quickly and works 24 hours a day. Machines that work quickly will cause engine parts to reduce work performance if not balanced with regular engine maintenance will cause the highest defects. From table 7 it can be seen that the potential failure mode which has the highest value is that there are air bubbles in the product when the dust press machine process with an RPN value of 324 . Thus DPM fails operation as the biggest cause of a defect. DPM failed an operation is a tool used to form powder produced from a spray drier machine into a flat shape which will later be formed into a glass bowl. This is due to the escape of air flow to the product, another cause is due to decreased engine performance due to age and maintenance problems.

Table 7. RPN Value for each failure modes

\begin{tabular}{|l|c|}
\hline Potential Failure Mode & RPN \\
\hline $\begin{array}{l}\text { Raw Material is not completely } \\
\text { destroyed }\end{array}$ & 48 \\
\hline Engine breakdown & 4 \\
\hline Human error (error weighing) & 24 \\
\hline $\begin{array}{l}\text { Error giving levels to mixing raw } \\
\text { material }\end{array}$ & 48 \\
\hline $\begin{array}{l}\text { There is still iron content in the raw } \\
\text { material }\end{array}$ & 96 \\
\hline $\begin{array}{l}\text { The machine cannot sift the } \\
\text { material stable. }\end{array}$ & 4 \\
\hline Addictive ingredients & 144 \\
\hline $\begin{array}{l}\text { Water content is less or more than } \\
1.8 \% \text {-2.2\% }\end{array}$ & 24 \\
\hline Granulate (less good ingredients) & 42 \\
\hline $\begin{array}{l}\text { Human Error (Error forming Glass } \\
\text { Bowl) }\end{array}$ & 42 \\
\hline $\begin{array}{l}\text { There are still air bubbles in the } \\
\text { dust press process }\end{array}$ & 324 \\
\hline human error & 84 \\
\hline Use of unstable rollers & 10 \\
\hline Temperature is not stable & 54 \\
\hline The material does not match the & 54 \\
\hline
\end{tabular}

\begin{tabular}{|l|c|}
\hline Kiln temperature & \\
\hline There is dust on the glazier material & 210 \\
\hline $\begin{array}{l}\text { Operators do not provide glazier } \\
\text { according to Regulation (Human }\end{array}$ & 270 \\
\begin{tabular}{l} 
Error) \\
\hline Image quality is not good
\end{tabular} & 100 \\
\hline $\begin{array}{l}\text { There is an air cavity in packing the } \\
\text { product }\end{array}$ & 150 \\
\end{tabular}

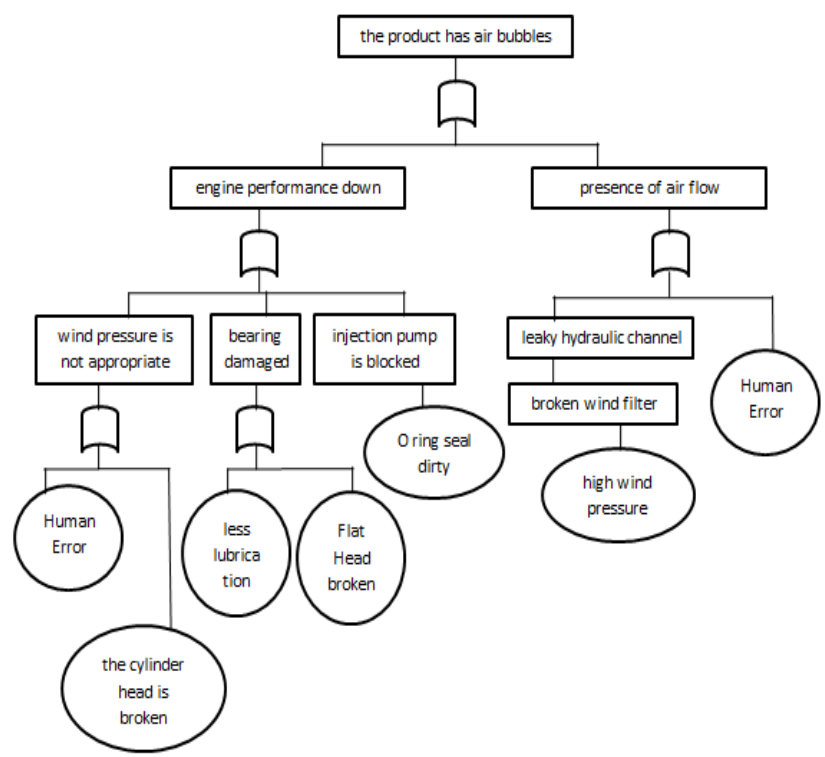

Fig. 2 Fault Tree Analysis Mode Failure of Machine Operation Failure

\section{CONCLUSION.}

Based on the results of the discussion above, some proposals for improvements given to the company as a whole are so that the company pays more attention to engine maintenance. this is intended to prevent the engine from failing its function. For treatment of the Dust Press Machine, more intensive care is needed because the DPM 900-07 engine has the highest RPN value compared to other machines.

\section{BIBLIOGRAPHY.}

Alsubiaee, K.M., Alotaibi, A.F., Alshehri, A.S. and Alassaf, M.A. (2017) 'Reverse Evaluation of Failure Mode and Effects Analysis Model: A New Reliable Performance Measurement', Journal of Arthritis, pp. $1-4$. 
Ambekar, S.B., Edlabadkar, A. and Shrouty, V. (2013) 'A Review: Implementation of Failure Mode and Effect Analysis', International Journal of Engineering and Innovative Technology, pp. 37-41.

Baig, A.A. and Ruzli, R. (2014) 'Estimation of Failure Probability Using Fault Tree Analysis and Fuzzy Logic for CO2 Transmission', International Journal of Environmental Science and Development, pp. 26-30.

Bašić, A. and Popović, P. (2016) 'Risk Assessment Of Mobile Phones Using Failure Mode And Effects Analysis', International Scientific Conference On Ict And E-Business Related Research, pp. 213-220.

Catic, D., Bojic, M., Glisovic, J., Djordjevic, Z. and Ratkovic, N. (2013) 'Fault Tree Analysis Of Solar Concentrators', International Journal for Quality Research, pp. 595-604.

Doshi, J. and Desai, D. (2016) 'Application Of Failure Mode \& Effect Analysis (Fmea) For Continuous Quality Improvement - Multiple Case Studies In Automobile Smes', International Journal for Quality Research , pp. 345-360.

ElMekkawy, T.Y., Hachkowski, P.A., Strong, D. and Mann, D.D. (2006) 'Defect analysis for quality and productivity improvements in a manufacturing system', Canadian Biosystem Engineering, pp. 816.

Gharahasanlou, A.N., Mokhtarei, A., Khodayarei, A. and Ataei, M. (2014) 'Fault tree analysis of failure cause of crushing plant and mixing bed hall at Khoy cement factory in Iran', Serbian journal of Management, pp. 33-38.

Hyman, W.A. and Johnson, E. (2008) 'Fault Tree Analysis of Clinical Alarms', pp. 85-94.
Nggada, S.H. (2012) 'Software Failure Analysis at Architecture Level using FMEA', International Journal of Software Engineering and Its Applications, pp. 61-74.

Nguyen, T.-L., Tai, D.H. and Shu, M.-H. (2016) 'Modifying risk priority number in failure modes and effects analysis', International Journal of Advanced and Applied Sciences, pp. 76-81.

Pandey, A., Singh, M., Sonawane, A.U. and Rawa, P.S. (2016) 'FMEA Based Risk Assessment of Component', International Journal of Engineering Trends and Technology (IJETT), pp. 216-225.

Parsana, T.S. and Patel, M.T. (2014) 'A Case Study: A Process FMEA Tool to Enhance Quality and Efficiency of Manufacturing Industry', Bonfring International Journal of Industrial Engineering and Management Science, pp. 145-152.

Patil, R.B., Waghmode, L.Y., Chikali, P.B. and Mulla, T.S. (2016) 'An Overview of Fault Tree Analysis (FTA) Method for Reliability Analysis \& Life Cycle Cost (LCC) Management', Journal of Mechanical \& Civil Engineering, pp. 14-18.

Popović, V., Vasić, B. and Petrović, M. (2010) 'The Possibility for FMEA Method Improvement and its Implementation into Bus Life Cycle ', Journal of Mechanical Engineering, pp. 1-7.

Putraa, G.P. and Purba, H.H. (2018) 'Failure Mode and Effect Aanalysis on Power Plant Boiler', Journal of Optimization in Industrial Engineering, pp. 1-5.

Rusin, A. and Wojaczek, A. (2012) 'Application of fault tree analysis in the maintenance intervals planning for power unit systems', journal of management and science, pp. 95-106. 
Sellappan, N. and Palanikumar, K. (2013) 'Modified Prioritization Methodology for Risk Priority Number in Failure Mode and Effects Analysis', International Journal of Applied Science and Technology, pp. 27-36.

Swarna, M.A. and Venkatakrishnaiah, R. (2014) 'Fault Tree Analysis in Construction Industry for Risk Management', International Journal of Advanced Research in Civil,Structural,Environmental and Infrastructure Engineering and Developing, pp. 15-21.

Tsarouhas, P.H. and Arampatzaki, D. (2015) 'Application of Failure Modes and Effects Analysis (FMEA) of a Ceramic Tiles Manufacturing Plant ', International Conference on Chain System, pp. 117.

verma, M., Kumar, A. and Singh, Y. (2012) 'Power System Reliability Evaluation Using Fault Tree Approach Based on Generalized Fuzzy Number', Journal of Fuzzy set Valued Analysis, pp. 1-13.

Wang, Y.-M., Chin, K.-S., Poon, G.K.K. and Yang, J.-B. (2009) 'Risk evaluation in failure mode and effects analysis using fuzzy weighted geometric mean', Expert Systems with Applications, pp. 1195-1207.

Wessiani, N.A. and Yoshio, F. (2017) 'Failure mode effect analysis and fault tree analysis as a combined methodology in risk management', International Conference on Industrial and System Engineering (IConISE), pp. 1-11.

Xiulia, L., Baozhia, C. and Hanqing, X. (2012) 'Study on Principle of Product Defect Identification', Procedia Engineering, pp. 393-398. 